Correspondence

Elena P. Ivanova

eivanova@swin.edu.au

\section{Sulfitobacter delicatus sp. nov. and Sulfitobacter dubius sp. nov., respectively from a starfish (Stellaster equestris) and sea grass (Zostera marina)}

\author{
Elena P. Ivanova, ${ }^{1,2}$ Nataliya M. Gorshkova, ${ }^{1}$ Tomoo Sawabe, ${ }^{3}$
} Natalia V. Zhukova, ${ }^{4}$ Karin Hayashi, ${ }^{3}$ Valerie V. Kurilenko, ${ }^{1}$ Yulia Alexeeva, ${ }^{2}$ Vlado Buljan, ${ }^{5}$ Dan V. Nicolau, ${ }^{2}$ Valery V. Mikhailov ${ }^{1}$ and Richard Christen ${ }^{5}$

${ }^{1}$ Pacific Institute of Bioorganic Chemistry of the Far-Eastern Branch of the Russian Academy of Sciences, 690022 Vladivostok, Pr. 100 Let Vladivostoku 159, Russia

${ }^{2}$ Industrial Research Institute, Swinburne University of Technology, PO Box 218, Hawthorn, Vic 3122, Australia

${ }^{3}$ Laboratory of Microbiology, Graduate School of Fisheries Sciences, Faculty of Fisheries, Hokkaido University, 3-1-1 Minato-cho, Hakodate 041-8611, Japan

${ }^{4}$ Institute of Marine Biology of the Far-Eastern Branch of the Russian Academy of Sciences, 690041 Vladivostok, Russia

${ }^{5}$ Muscle Research Unit, Institute for Biomedical Research, The University of Sydney, Sydney 2006, Australia

'UMR 6543 CNRS and Université de Nice Sophia Antipolis, Centre de Biochimie, Parc Valrose, F-06108 Nice cedex 2, France

On the basis of data from phenotypic and genotypic characterization and analysis of 16S rRNA gene sequences, two novel species belonging to the genus Sulfitobacter are described. Strains KMM $3584^{\top}$, a pale-yellowish, non-motile strain isolated from a starfish (Stellaster equestris), and $\mathrm{KMM} 3554^{\mathrm{T}}$, which is motile by means of a single subpolar flagellum and was isolated from sea grass (Zostera marina), are marine, Gram-negative, aerobic, rod-shaped organisms. Both strains have the ability to degrade gelatin, but not casein, chitin, agar, DNA, Tween 80 or starch. Strain $\mathrm{KMM} 3584^{\mathrm{T}}$ decomposed alginate and grew at $\mathrm{NaCl}$ concentrations of $1-8 \%$ and temperatures of $12-37^{\circ} \mathrm{C}$, whereas strain $\mathrm{KMM} 3554^{\top}$ grew in $1-12 \% \mathrm{NaCl}$ and at temperatures of $10-30^{\circ} \mathrm{C}$. The predominant fatty acid was $18: 1 \omega 7$, amounting to up to $80 \%$ of the total fatty acids. The other characteristic feature was the presence of $18: 2$ isomers. The DNA G $+C$ contents of $\mathrm{KMM} 3584^{\top}$ and $\mathrm{KMM} 3554^{\top}$ were respectively $60 \cdot 0$ and $63 \cdot 7 \mathrm{~mol} \%$. The level of DNA similarity between the two strains was $33 \%$. DNA from $\mathrm{KMM} 3584^{\top}$ and $\mathrm{KMM} 3554^{\top}$ had hybridization values of $5-24 \%$ and $10-41 \%$, respectively, with DNA from the type strains of Sulfitobacter pontiacus, Sulfitobacter brevis, Sulfitobacter mediterraneus and Staleya guttiformis.

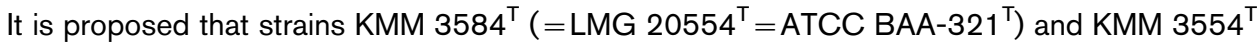
$\left(=\mathrm{LMG} 20555^{\top}=\mathrm{ATCC}^{\left.\mathrm{BAA}-320^{\top}\right)}\right.$ represent two novel species, Sulfitobacter delicatus sp. nov. and Sulfitobacter dubius sp. nov., respectively.
Published online ahead of print on 18 September 2003 as DOI 10.1099/ijs.0.02654-0.

Abbreviations: ML, maximum-likelihood; MP, maximum-parsimony; $\mathrm{NJ}$, neighbour-joining.

The GenBank accession numbers for the $16 \mathrm{~S}$ rRNA gene sequences of $\mathrm{KMM} 3584^{\top}$ and $\mathrm{KMM} 3554^{\top}$ are AY180103 and AY180102.

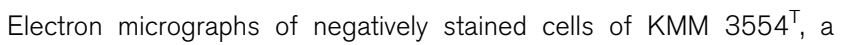
similarity matrix table and an extended phylogenetic tree are available as supplementary material in IJSEM Online.
The genus Sulfitobacter currently comprises three species, Sulfitobacter pontiacus, Sulfitobacter mediterraneus and Sulfitobacter brevis. This genus was created in 1995 to accommodate two strains of heterotrophic bacteria isolated from the $\mathrm{H}_{2} \mathrm{~S} / \mathrm{O}_{2}$ interface of the Black Sea (Sorokin, 1995). Bacteria of this genus were subsequently detected in samples of natural sea water collected in the Mediterranean Sea (Pukall et al., 1999) and in the hypersaline Ekho Lake of east Antarctica (Labrenz et al., 2000). Phylogenetically, 
bacteria of this taxon are closely related to bacteria of the recently proposed genus Staleya, which currently contains one species (Staleya guttiformis; Labrenz et al., 2000), and moderately related to bacteria of the genus Roseobacter. According to recent data, representatives of Sulfitobacter can be considered as rather ubiquitous marine bacteria that are widely distributed in coastal and open-ocean environments, namely the Black Sea (Sorokin, 1995), Sargasso Sea (Suzuki et al., 1997) and Antarctica (Labrenz et al., 2000), where they may play an important role in organic sulfur cycling in the ocean.

This study extends our previous investigations into the biodiversity of marine proteobacteria from the Sea of Japan, the north-west Pacific Ocean and other geographical locations (Ivanova et al., 1996, 1998, 2000; Sawabe et al., 2000). During isolation studies, bacteria of various taxonomic groups, including species of Shewanella, Marinobacter, Halomonas and Pseudoalteromonas, have been isolated (E. P. Ivanova, unpublished results; Kurilenko et al., 2001). However, only two strains with Sulfitobacterlike phenotypes have been tentatively identified. The strains examined in this study were isolated from a starfish (Stellaster equestris) and sea grass (Zostera marina). The starfish was collected in October 1998 at a depth of $100 \mathrm{~m}$ (salinity $30 \%$, temperature $15{ }^{\circ} \mathrm{C}$ ) in the South China Sea $\left(26^{\circ} 28 \cdot 3^{\prime} \mathrm{N} 122^{\circ} 29 \cdot 0^{\prime} \mathrm{E}\right)$. The sea grass was collected in July 1998 at a depth of 5-8 m (salinity $33 \%$, temperature $12{ }^{\circ} \mathrm{C}$ ) at the Pacific Institute of Bio-organic Chemistry Marine Experimental Station, Troitza Bay, Gulf of Peter the Great, Sea of Japan. The starfish and sea grass were pre-rinsed in sterilized sea water and pieces of tissue (about $3 \mathrm{~g}$ ) were aseptically removed. Strains were isolated by plating samples of tissue homogenate $(0.1 \mathrm{ml})$ onto marine agar 2216 (Difco) plates and medium B plates. Medium B contained the following [in $50 \%(\mathrm{v} / \mathrm{v})$ natural sea water and $50 \%(\mathrm{v} / \mathrm{v})$ distilled water at $\mathrm{pH} 7 \cdot 5-7 \cdot 8$, as described previously (Ivanova et al., 1996)]: 0.2\% (w/v) Bacto peptone (Difco); 0.2\% (w/v) casein hydrolysate (Merck); $0 \cdot 2 \%(\mathrm{w} / \mathrm{v}$ ) Bacto yeast extract (Difco); $0 \cdot 1 \%$ $(\mathrm{w} / \mathrm{v})$ glucose; $0.02 \%(\mathrm{w} / \mathrm{v}) \quad \mathrm{KH}_{2} \mathrm{PO}_{4} ; 0.005 \%(\mathrm{w} / \mathrm{v})$ $\mathrm{MgSO}_{4} .7 \mathrm{H}_{2} \mathrm{O}$; and $1.5 \%$ (w/v) Bacto agar (Difco).

Phenotypic properties used for characterization of Sulfitobacter species were assessed using standard procedures (Smibert \& Krieg, 1994) and as described elsewhere (Ivanova et al., 1996, 1998). The bacteria were grown at $22-24^{\circ} \mathrm{C}$. Motility was studied in hanging drop preparations. The following physiological and biochemical properties were examined: oxidation/fermentation of glucose (Hugh \& Leifson, 1953); Gram staining; reduction of nitrate and nitrite; catalase (with $5 \% \mathrm{H}_{2} \mathrm{O}_{2}$ ) and oxidase (Kóvacs, 1956) activities; gelatin liquefaction; production of arginine dihydrolase, lysine decarboxylase, ornithine decarboxylase, poly- $\beta$-hydroxybutyrate and acetoin (Voges-Proskauer test); sodium requirement $[0,1,3,6,8,10,12,15 \%(\mathrm{w} / \mathrm{v})$ $\mathrm{NaCl}$; indole and $\mathrm{H}_{2} \mathrm{~S}$ production; and the ability to hydrolyse starch, Tween 80 , casein, DNA, chitin, agar and alginate. The temperature range for growth was examined on marine agar incubated at $4,10,30,35,37$ and $42{ }^{\circ} \mathrm{C}$. Haemolytic activity of the strains was detected on blood agar containing $40 \mathrm{~g}$ trypticase soy agar in $50 \mathrm{ml}$ sheep blood and $950 \mathrm{ml}$ water. Oxidative utilization of 95 carbon sources was tested using Biolog GN Microplates (Rüger \& Krambeck, 1994) as described elsewhere (Ivanova et al., 1998). The ability to oxidize sulfite was tested as described by Pukall et al. (1999). Susceptibility to antibiotics was tested by the conventional diffusion plate technique using solid medium B and discs impregnated with following antibiotics: kanamycin $(30 \mu \mathrm{g})$, ampicillin $(10 \mu \mathrm{g})$, benzylpenicillin $(10 \mathrm{U})$, streptomycin $(10 \mu \mathrm{g})$, erythromycin $(15 \mu \mathrm{g})$, gentamicin $(10 \mu \mathrm{g})$, oxacillin $(20 \mathrm{U})$, lincomycin $(15 \mu \mathrm{g})$, carbenicillin $(100 \mathrm{U})$, vancomycin $(30 \mu \mathrm{g})$, tetracycline $(30 \mu \mathrm{g})$, oleandomycin $(15 \mu \mathrm{g})$ and $\mathrm{O} / 129(150 \mu \mathrm{g})$.

Cellular morphology was examined by phase-contrast light microscopy of 24-h-old cultures grown on agar plates. Electron micrographs of negatively stained cells were prepared using a Zeiss EM 10 CA electron microscope $(80 \mathrm{kV})$. A drop of particle-free (autoclaved and ultracentrifuged) distilled water was placed on the culture. The sample $(30 \mu \mathrm{l})$ of resulting bacterial suspension was applied to carbon- and Formvar-coated 400-mesh copper grids, a drop of $1.25 \%$ uranyl acetate was added and the bacteria were allowed to adhere for $1 \mathrm{~min}$ at room temperature. Superfluous liquid was gently removed using a piece of filter paper.

Lipids were extracted from wet cells by the method of Bligh \& Dyer (1959). Two-dimensional micro-TLC of polar lipids was carried out according to the method of Svetashev \& Vaskovsky (1972) using chloroform/ methanol/benzene/28\% $\mathrm{NH}_{4} \mathrm{OH}(65: 30: 10: 6$, by vol. $)$ for the first direction and chloroform/methanol/benzene/ acetone/acetic acid/water $(70: 30: 10: 5: 4: 1$, by vol.) for the second one. Non-specific detection of lipids on the TLC was performed with a $10 \% \mathrm{H}_{2} \mathrm{SO}_{4}$ solution in methanol with charring at $180^{\circ} \mathrm{C}$ (Kates, 1986). The following specific reagents were used: for phospholipids, see Vaskovsky et al. (1975); $2 \%$ ninhydrin in acetone for amino-containing lipids; Dragendorff's reagent for choline lipids; and anthrone spray $(0.5 \%$ anthrone in benzene and $5 \% \mathrm{H}_{2} \mathrm{SO}_{4}$ in water) for glycolipids. Phosphorus analysis was carried out according to Vaskovsky et al. (1975). The phospholipid compositions of the isolates studied were generally similar. Phosphatidylglycerol was the major constituent of the phospholipids, accounting for $66 \%$ total phospholipid. The strains contained significant amounts of phosphatidylethanolamine (up to $14 \cdot 2 \%$ ) and phosphatidylcholine (up to $18 \%$ ). Diphosphatidylglycerol was present in smaller amounts (3-8\%).

Fatty acid methyl esters were prepared as described elsewhere (Svetashev et al., 1995) and analysed on a Shimadzu GC-14A GC with an FID using both a non-polar SPB-5 fused-silica column $(30 \mathrm{~m} \times 0 \cdot 25 \mathrm{~mm}$ i.d. $)$ at $210^{\circ} \mathrm{C}$ and a polar Supelcowax-10 fused-silica column $(30 \mathrm{~m} \times 0.25 \mathrm{~mm}$ 
Table 1. DNA relatedness among tested strains

\begin{tabular}{|c|c|c|c|}
\hline \multirow[t]{2}{*}{ Strain } & \multirow[t]{2}{*}{$\begin{array}{c}\mathrm{G}+\mathrm{C} \text { content } \\
(\mathrm{mol} \%)\end{array}$} & \multicolumn{2}{|c|}{$\begin{array}{l}\text { Hybridization (\%) with } \\
\text { biotinylated DNA from: }\end{array}$} \\
\hline & & KMM $3584^{\mathrm{T}}$ & KMM $3554^{\mathrm{T}}$ \\
\hline Sulfitobacter delicatus KMM $3584^{\mathrm{T}}$ & $60 \cdot 0$ & $100 \cdot 0$ & $33 \cdot 4$ \\
\hline Sulfitobacter dubius KMM $3554^{\mathrm{T}}$ & $63 \cdot 7$ & $32 \cdot 8$ & $100 \cdot 0$ \\
\hline Sulfitobacter pontiacus DSM $10014^{\mathrm{T}}$ & $62 \cdot 1$ & $13 \cdot 4$ & $22 \cdot 1$ \\
\hline Sulfitobacter mediterraneus ATCC $700856^{\mathrm{T}}$ & $59 \cdot 0$ & $24 \cdot 2$ & $41 \cdot 2$ \\
\hline Sulfitobacter brevis ATCC BAA $-4^{\mathrm{T}}$ & $58 \cdot 0$ & $16 \cdot 1$ & $12 \cdot 1$ \\
\hline Staleya guttiformis DSM $11458^{\mathrm{T}}$ & $55 \cdot 5$ & $5 \cdot 4$ & $10 \cdot 0$ \\
\hline
\end{tabular}

i.d.) at $200{ }^{\circ} \mathrm{C}$. Analysis of cellular fatty acids of Sulfitobacterlike isolates revealed that the strains studied had a characteristic genus-specific pattern of fatty acids. Of 17 identified

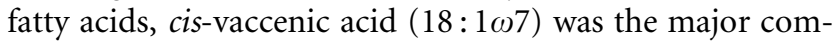

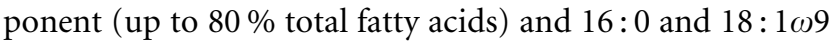
were detected at levels of 4-4-7·8\%. $10: 03-\mathrm{OH}, 16: 1 \omega 7$, $17: 0$ and $18: 2$ isomers were present as minor components, which is consistent with the data of Pukall et al. (1999) and Labrenz et al. (2000).

Sulfitobacter pontiacus DSM $10014^{\mathrm{T}}$, Sulfitobacter mediterraneus ATCC $700856^{\mathrm{T}}$ and Sulfitobacter brevis ATCC BAA $-4^{\mathrm{T}}$, obtained from the German Collection of Microorganisms and the American Type Culture Collection, were used for comparing phenotypic properties and DNA-DNA hybridization experiments. Staleya guttiformis DSM $11458^{\mathrm{T}}$ was a generous gift from P. Hirsch (Institut für Allgemeine Mikrobiologie, Kiel, Germany). All the reference strains were routinely cultured on marine agar 2216 plates (Difco) and PYGV agar plates (Staley, 1968). DNA was isolated from the strains by the method of Marmur (1961). The G+C content of the DNA was determined using the thermal denaturation method (Marmur \& Doty, 1962). DNA-DNA hybridization experiments were performed using covalent attachment of the DNA in micro-wells according to the method evaluated by Christensen et al. (2000). The level of DNA-DNA relatedness between the two strains studied was $33 \%$ and they were therefore genotypically assigned to separate species. The genetic similarity of $\mathrm{KMM} 3584^{\mathrm{T}}$ to type strains of the genus Sulfitobacter and Staleya guttiformis was rather low (5-24\%) (Table 1); for KMM 3554 ${ }^{\mathrm{T}}$, the similarity was $10-41 \%$. Based on the generally accepted criterion of the definition of genomic species (Wayne et al., 1987), strains KMM $3584^{\mathrm{T}}$ and $\mathrm{KMM} 3554^{\mathrm{T}}$ are representatives of novel species.

The small-subunit rRNA genes were sequenced as described elsewhere (Sawabe et al., 1998a, b). The 16S rRNA gene sequences of KMM $3584^{\mathrm{T}}$ and KMM $3554^{\mathrm{T}}$ were aligned automatically and then manually by reference to a database of 86000 previously aligned bacterial 16S rRNA gene sequences. Phylogenetic trees were constructed according to three methods [BIONJ, maximum-likelihood (ML) and maximum-parsimony (MP)]. For neighbour-joining (NJ) analysis, distance matrices were calculated using the Kimura two-parameter correction. BIONJ was according to Gascuel (1997) and ML and MP were from PHYLIP (Phylogeny Inference Package, version 3.573c, distributed by J. Felsenstein, Department of Genetics, UW, Seattle, WA, USA). Only parts of the sequences that could be properly aligned were used for the tree depicted; they correspond to positions $60-1273$ of the KMM $3554^{\mathrm{T}}$ sequence. The phylogenetic trees were drawn using NJPLOT (Perrière \& Gouy, 1996). Fig. 1 shows a consensus tree between NJ (bootstrap analysis, 1000 replications), ML and MP analysis. The topology shown is that of the bootstrap tree, as it has been demonstrated that this topology is often better than that of a simple tree (Berry \& Gascuel, 1996).

The most similar sequence to those of the novel isolates was that of 'Oceanibulbus indoliflex' (99.5\%), followed by sequences from Sulfitobacter brevis, Sulfitobacter pontiacus,

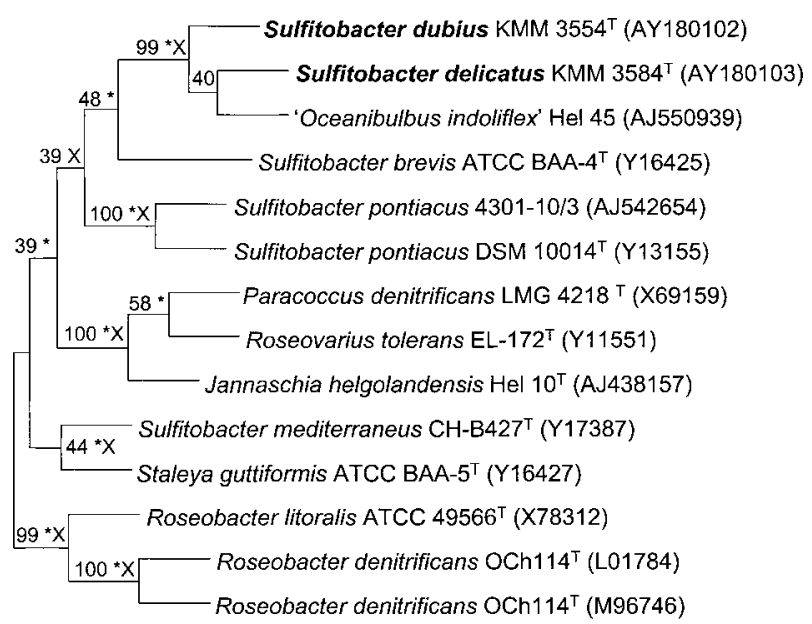

Fig. 1. Phylogenetic position of Sulfitobacter delicatus sp. nov. $\mathrm{KMM} 3584^{\top}$ and Sulfitobacter dubius sp. nov. KMM $3554^{\top}$ according to $16 \mathrm{~S}$ rRNA gene sequence analysis. The unrooted tree shown is the result of a neighbour-joining bootstrap analysis (1000 replications). Values shown are bootstrap percentages. Branches that were also retrieved by parsimony (three most parsimonious trees) and maximum-likelihood $(\ln =-3506)$ are respectively indicated by * and $\mathrm{X}(P<0.01)$. 
Sulfitobacter mediterraneus and Staleya guttiformis $(\leqslant 97 \cdot 8 \%)$ (but see the table available as supplementary material in IJSEM Online). An initial first analysis included the 79 most similar sequences as retrieved by BLAST on EMBL and EMBL new (a tree is available as supplementary material in IJSEM Online). Removal of sequences pertaining to species that were uncultured and not validly named led to a dataset of 14 sequences that were visually aligned and analysed by all three methods (see Fig. 1). The two KMM sequences grouped robustly with ' $O$. indoliflex', a species that is yet to be described, but not with any species with validly published names, suggesting that each of these sequences represents a novel bacterial species, as confirmed by DNA-DNA hybridization experiments (Table 1). These two species clustered with the type species of the genus Sulfitobacter (Sulfitobacter pontiacus) according to NJ and ML, but not MP, and the degree of bootstrap replication was low (39\%), suggesting that the genus Sulfitobacter might be subject to revision in the future, probably to include only the type species of the genus. Such a revision may require phylogenetic analyses of more housekeeping genes; it is therefore suggested that the two novel species be assigned to the genus Sulfitobacter for the time being.

The two novel species can be distinguished from other Sulfitobacter species and Staleya guttiformis by a number of phenotypic traits (Table 2). For example, strain KMM $3584^{\mathrm{T}}$ is able to hydrolyse gelatin and alginate and does not utilize melibiose, whereas strain KMM $3554^{\mathrm{T}}$ is more halophilic, hydrolyses only gelatin and utilizes citrate and melibiose. Both novel species are unable to produce DNase or lipase. The names Sulfitobacter delicatus sp. nov. and Sulfitobacter dubius sp. nov. are proposed for KMM $3584^{\mathrm{T}}$ and KMM $3554^{\mathrm{T}}$, respectively.

\section{Description of Sulfitobacter delicatus sp. nov.}

Sulfitobacter delicatus (de.li.ca'tus. L. masc. adj. delicatus beautiful).

Rod-shaped cells, single, about $0 \cdot 7-0.9 \mu \mathrm{m}$ in diameter. Gram-negative. Non-motile. Chemo-organotroph with respiratory metabolism. Colonies are uniformly round, 1-3 $\mathrm{mm}$ in diameter, regular, convex, smooth and slightly yellowish after incubation for $48-74 \mathrm{~h}$ on marine agar. No diffusible pigment is produced in the medium. Does not form endospores. Accumulates poly- $\beta$-hydroxybutyrate as an intracellular reserve product. Oxidase- and catalasepositive. Requires $\mathrm{Na}^{+}$or sea water for growth. Growth occurs in media containing $1-8 \% \mathrm{NaCl}$. Mesophilic. Grows at $12-37^{\circ} \mathrm{C}$ and $\mathrm{pH} 6 \cdot 0-10 \cdot 0$; optimum growth is observed at $25^{\circ} \mathrm{C}$ and $\mathrm{pH} 7 \cdot 5-8 \cdot 0$. No growth is detected at $40^{\circ} \mathrm{C}$. Decomposes gelatin and alginate. Agar, starch, casein, laminarin, Tween 80 and DNA are not hydrolysed. From the 95 carbon sources tested, according to Biolog, $\alpha$-cyclodextrin, glycogen, i-erythritol, psicose, D-raffinose, L-rhamnose, acetic acid, D-galactonic acid lactone, D-galacturonic acid, D-glucuronic acid, $\alpha$-ketovaleric acid, glucuronamide, L-leucine, L-ornithine, D-serine, DL-carnitine, urocanic acid, thymidine, phenylethylamine, putrescine, 2-aminoethanol, 2,3-butandiol, DL- $\alpha$-glycerolphosphate

Table 2. Characteristics that differentiate Sulfitobacter delicatus sp. nov. KMM $3584^{\top}$ and Sulfitobacter dubius sp. nov. KMM $3554^{\top}$ from phylogenetically related species

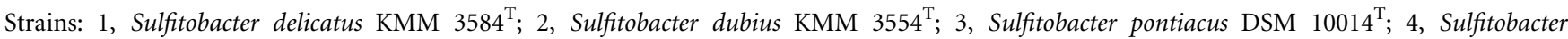
mediterraneus ATCC $700856^{\mathrm{T}}$; 5, Sulfitobacter brevis ATCC BAA-4 ${ }^{\mathrm{T}} ; 6$, Staleya guttiformis DSM $11458^{\mathrm{T}}$. None of the strains tested produced laminarinase or chitinase. +, Positive; -, negative; W, weak reaction. Data from this study and from Sorokin (1995), Pukall et al. (1999) and Labrenz et al. (2000).

\begin{tabular}{|c|c|c|c|c|c|c|}
\hline Characteristic & 1 & 2 & 3 & 4 & 5 & 6 \\
\hline DNA G $+\mathrm{C}$ content $(\mathrm{mol} \%)$ & $60 \cdot 0$ & $63 \cdot 7$ & $62 \cdot 1$ & $59 \cdot 0$ & $57 \cdot 9-58 \cdot 1$ & $55 \cdot 0-56 \cdot 3$ \\
\hline Temperature range for growth $\left({ }^{\circ} \mathrm{C}\right)$ & $12-37$ & $10-30$ & $4-35$ & $4-35$ & $3-26$ & $12-20$ \\
\hline $\mathrm{NaCl}$ range for growth $(\%, \mathrm{w} / \mathrm{v})$ & $1-8$ & $1-12$ & $0 \cdot 5-8 \cdot 0$ & $0 \cdot 2-8 \cdot 0$ & $1-2$ & $1-4$ \\
\hline Sulfite oxidation & + & + & + & + & - & - \\
\hline \multicolumn{7}{|l|}{ Production of: } \\
\hline DNase & - & - & - & - & - & + \\
\hline Lipase (Tween 80) & + & - & + & + & + & + \\
\hline Amylase & - & - & + & + & - & - \\
\hline Alginase & + & - & - & - & - & - \\
\hline Gelatinase & + & + & - & + & - & - \\
\hline Haemolysis & - & - & - & + & - & - \\
\hline Nitrate reduction & $\mathrm{W}$ & + & + & - & - & + \\
\hline \multicolumn{7}{|l|}{ Utilization of: } \\
\hline Melibiose & - & + & $\mathrm{W}$ & - & + & $\mathrm{W}$ \\
\hline D-Glucose & - & - & $\mathrm{W}$ & + & $\mathrm{W}$ & $\mathrm{W}$ \\
\hline Citrate & - & + & $\mathrm{W}$ & + & + & - \\
\hline
\end{tabular}


and glucose 1-phosphate are not utilized and L-fucose, Dgalactose, gentiobiose, $\alpha$-lactose, D-mannitol and hydroxyproline are only weakly utilized. Susceptible to ampicillin, benzylpenicillin, gentamicin, kanamycin, carbenicillin, neomycin, oleandomycin and streptomycin; not susceptible to polymyxin or tetracycline. Phosphatidylglycerol, phosphatidylethanolamine and phosphatidylcholine are the major phospholipids. The main cellular fatty acid is cisvaccenic acid (approx. $80 \%$ ).

The type strain is KMM $3584^{\mathrm{T}}\left(=\mathrm{LMG} 20554^{\mathrm{T}}=\mathrm{ATCC}\right.$ BAA- $321^{\mathrm{T}}$ ). The $\mathrm{G}+\mathrm{C}$ content of the DNA of the type strain is $60.3 \mathrm{~mol} \%$. Isolated from a starfish (Stellaster equestris) collected from the South China Sea.

\section{Description of Sulfitobacter dubius sp. nov.}

Sulfitobacter dubius (du'bi.us. L. masc. adj. dubius doubtful).

Rod-shaped cells, single, about $0 \cdot 6-0 \cdot 8 \mu \mathrm{m}$ in diameter and $1 \cdot 2-1 \cdot 5 \mu \mathrm{m}$ long with a single subpolar flagellum (see figure available as supplementary material in IJSEM Online). Gram-negative. Chemo-organotroph with respiratory metabolism. Colonies are uniformly round, 1-3 mm in diameter, regular, convex, smooth, slightly yellowish after incubation for $48 \mathrm{~h}$ on marine agar. No diffusible pigment is produced in the medium. Does not form endospores. Accumulates poly- $\beta$-hydroxybutyrate as an intracellular reserve product. Oxidase- and catalasepositive. Requires $\mathrm{Na}^{+}$or sea water for growth. Growth occurs in media containing $1-12 \% \mathrm{NaCl}$. Grows at 10 $30^{\circ} \mathrm{C}$ and $\mathrm{pH} 6 \cdot 0-11 \cdot 0$; optimum growth is observed at $25^{\circ} \mathrm{C}$ and $\mathrm{pH} 7 \cdot 5-8 \cdot 0$. No growth is detected at $35^{\circ} \mathrm{C}$. Decomposes gelatin. Agar, starch, casein, laminarin, alginate, Tween 80 and DNA are not hydrolysed. From the 95 carbon sources tested, according to Biolog, i-erythritol, D-raffinose, thymidine, phenylethylamine, putrescine and 2 -aminoethanol are not utilized and $\alpha$ cyclodextrin, glycogen, L-fucose, D-galactose, L-rhamnose, D-sorbitol, D-galactonic acid lactone, D-galacturonic acid, glucuronamide, L-phenylalanine, L-pyroglutamic acid, D-serine and glucose 1-phosphate are only weakly utilized. Susceptible to ampicillin, benzylpenicillin, gentamicin, kanamycin, carbenicillin, neomycin, oleandomycin and streptomycin; not susceptible to polymyxin, tetracycline or lincomycin. Phosphatidylglycerol, phosphatidylethanolamine and phosphatidylcholine are the major phospholipids. The main cellular fatty acid is cis-vaccenic acid (approx. $80 \%$ ).

The type strain is KMM $3554^{\mathrm{T}}\left(=\mathrm{LMG} 20555^{\mathrm{T}}=\mathrm{ATCC}\right.$ BAA $-320^{\mathrm{T}}$ ). The $\mathrm{G}+\mathrm{C}$ content of DNA of the type strain is $63.7 \mathrm{~mol} \%$. Isolated from sea grass (Zostera marina) collected from the Sea of Japan.

\section{Acknowledgements}

This study was partially supported by funds from the Russian Foundation for Basic Research (RFBR) no. 02-04-49517 and grant
\#03-19 from the Ministry for Industry, Science and Technology of Russian Federation and partially supported by the Science Support Foundation of the Russian Academy of Sciences grant for talented researchers.

\section{References}

Berry, V. \& Gascuel, O. (1996). Interpretation of bootstrap trees: threshold of clade selection and induced gain. Mol Biol Evol 13, 999-1011.

Bligh, E. G. \& Dyer, W. J. (1959). A rapid method of total lipid extraction and purification. Can J Biochem Physiol 37, 911-917.

Christensen, H., Angen, Ø., Mutters, R., Olsen, J. E. \& Bisgaard, M. (2000). DNA-DNA hybridization determined in micro-wells using covalent attachment of DNA. Int J Syst Evol Microbiol 50, 1095-1102.

Gascuel, O. (1997). BIONJ: an improved version of the NJ algorithm based on a simple model of sequence data. Mol Biol Evol 14, 685-695.

Hugh, R. \& Leifson, E. (1953). The taxonomic significance of fermentative versus oxidative metabolism of carbohydrates by various Gram-negative bacteria. J Bacteriol 66, 24-26.

Ivanova, E. P., Kiprianova, E. A., Mikhailov, V. V., Levanova, F. G., Garagulya, A. G., Gorshkova, N. M., Yumoto, N. \& Yoshikawa, S. (1996). Characterization and identification of marine Alteromonas nigrifaciens strains and emendation of the description. Int J Syst Bacteriol 46, 223-228.

Ivanova, E. P., Kiprianova, E. A., Mikhailov, V. V. \& 8 other authors (1998). Phenotypic diversity of Pseudoalteromonas citrea from different marine habitats and emendation of the description. Int J Syst Bacteriol 48, 247-256.

Ivanova, E. P., Romanenko, L. A., Chun, J. \& 7 other authors (2000). Idiomarina gen. nov., comprising novel indigenous deep-sea bacteria from the Pacific Ocean, including description of two species, Idiomarina abyssalis sp. nov. and Idiomarina zobellii sp. nov. Int J Syst Evol Microbiol 50, 901-907.

Kates, M. (1986). Techniques in Lipidology. New York: Elsevier.

Kóvacs, N. (1956). Identification of Pseudomonas pyocyanea by the oxidase reaction. Nature 178, 703.

Kurilenko, V. V., Ivanova, E. P. \& Mikhailov, V. V. (2001). Zonal distribution of epiphytic microorganisms on the sea grass Zostera marina. Mikrobiologiya 70, 427-428 (in Russian).

Labrenz, M., Tindall, B. J., Lawson, P. A., Collins, M. D., Schumann, P. \& Hirsch, P. (2000). Staleya guttiformis gen. nov., sp. nov. and Sulfitobacter brevis sp. nov., $\alpha$-3-Proteobacteria from hypersaline, heliothermal and meromictic Antarctic Ekho Lake. Int J Syst Evol Microbiol 50, 303-313.

Marmur, J. (1961). A procedure for the isolation of deoxyribonucleic acid from microorganisms. J Mol Biol 3, 208-218.

Marmur, J. \& Doty, P. (1962). Determination of the base composition of deoxyribonucleic acid from its thermal denaturation temperature. J Mol Biol 4, 109-118.

Perrière, G. \& Gouy, M. (1996). WWW-query: an on-line retrieval system for biological sequence banks. Biochimie 78, 364-369.

Pukall, R., Buntefuß, D., Frühling, A., Rohde, M., Kroppenstedt, R. M., Burghardt, J., Lebaron, P., Bernard, L. \& Stackebrandt, E. (1999). Sulfitobacter mediterraneus sp. nov., a new sulfite-oxidizing member of the $\alpha$-Proteobacteria. Int J Syst Bacteriol 49, 513-519.

Rüger, H.-J. \& Krambeck, H.-J. (1994). Evaluation of the BIOLOG substrate metabolism system for classification of marine bacteria. Syst Appl Microbiol 17, 281-288.

Sawabe, T., Sugimura, I., Ohtsuka, M., Nakano, K., Tajima, K., Ezura, Y. \& Christen, R. (1998a). Vibrio halioticoli sp. nov., a 
non-motile alginolytic marine bacterium isolated from the gut of the abalone Haliotis discus hannai. Int J Syst Bacteriol 48, 573-580.

Sawabe, T., Makino, H., Tatsumi, M., Nakano, K., Tajima, K., Iqbal, M. M., Yumoto, I., Ezura, Y. \& Christen, R. (1998b). Pseudoalteromonas bacteriolytica sp. nov., a marine bacterium that is the causative agent of red spot disease of Laminaria japonica. Int J Syst Bacteriol 48, 769-774.

Sawabe, T., Tanaka, R., lqbal, M. M., Tajima, K., Ezura, Y., Ivanova, E. P. \& Christen, R. (2000). Assignment of Alteromonas elyakovii KMM $162^{\mathrm{T}}$ and five strains isolated from spot-wounded fronds of Laminaria japonica to Pseudoalteromonas elyakovii comb. nov. and the extended description of the species. Int J Syst Evol Microbiol 50, 265-271.

Smibert, R. M. \& Krieg, N. R. (1994). Phenotypic characterization. In Methods for General and Molecular Bacteriology, pp. 607-654. Edited by P. Gerhardt, R. G. E. Murray, W. A. Wood \& N. R. Krieg. Washington, DC: American Society for Microbiology.

Sorokin, D. Y. (1995). Sulfitobacter pontiacus gen. nov., sp. nov. - a new heterotrophic bacterium from the Black Sea, specialized on sulfite oxidation. Mikrobiologiya 64, 354-365 (English translation, 295-305).

Staley, J. T. (1968). Prosthecomicrobium and Ancalomicrobium: new prosthecate freshwater bacteria. J Bacteriol 95, 1921-1942.

Suzuki, M. T., Rappe, M. S., Haimberger, Z. W., Winfield, H., Adair, N., Strobel, J. \& Giovannoni, S. J. (1997). Bacterial diversity among small-subunit rRNA gene clones and cellular isolates from the same seawater sample. Appl Environ Microbiol 63, 983-989.

Svetashev, V. I. \& Vaskovsky, V. E. (1972). A simplified technique for thin-layer microchromatography of lipids. J Chromatogr 67, 376-378.

Svetashev, V. I., Vysotskii, M. V., Ivanova, E. P. \& Mikhailov, V. V. (1995). Cellular fatty acids of Alteromonas species. Syst Appl Microbiol 18, 37-43.

Vaskovsky, V. E., Kostetsky, E. Y. \& Vasendin, I. M. (1975). A universal reagent for phospholipid analysis. J Chromatogr 114, 129-141.

Wayne, L. G., Brenner, D. J., Colwell, R. R. \& 9 other authors (1987). International Committee on Systematic Bacteriology. Report of the ad hoc committee on reconciliation of approaches to bacterial systematics. Int J Syst Bacteriol 37, 463-464. 